\title{
EFFECTIVENESS OF ENVIRONMENTAL MANAGEMENT BASED ON TRASH IN THE CITY OF DEPOK
}

\author{
Ismiyati $^{1}$, Irfan Purnawan ${ }^{1}$ and Muh. Kadarisman ${ }^{2}$ \\ ${ }^{1}$ Department of Chemical Engineering, Faculty of Engineering, University of Muhammadiyah Jakarta, Indonesia \\ ${ }^{2}$ Department of Public Administration Science, Faculty of Social and Politic Sciences, University of Muhammadiyah Jakarta, Indonesia \\ E-mail: ismiyati.umj@gmail.com
}

\begin{abstract}
ABSTRAK
Indonesian government efforts, particularly in the city of Depok, regarding decent and healthy environmental management in the waste sector have to be enhanced. This is a complex and diverse problems, even though the government has set into the form of Law (UU) Number 18 Year 2008 on Waste Management to build a strategic partnership of stakeholders in waste management. The Government has also issued Government Regulation of the Republic of Indonesia Number 81 Year 2012 on "Management of household waste and household-like waste". Further research is required on what extent that the implementation of waste management had been undertaken, as well as the necessity to study the methods of environmental insight in waste management. Waste management needs to be comprehensive and integrated from upstream to downstream, thus providing economic benefits, people healthiness and environmental safety. The purpose of this study is to analyze the effectiveness of environmental management based in Depok. This study uses qualitative design, which is to observe, understand and expose reality or empirical phenomena; hence the proper method used is descriptive method. Instrument to gather the data is completed by observation and in-depth interviews. The type of data required includes primary and secondary data. The informant is selected by purposive sampling, and data analysis is treated with triangulation technique. The results present that in the framework of the effectiveness of environmental management based trash in Depok showed that 1) Institutional Factor for Urban Waste Management of Depok has run properly, 2) Private partnership (commercial solution) to be involved in urban waste management in Depok is being explored, 3) Applicable technology in fostering a culture of 3R (reduce, reuse and recycle) on the entire community of Depok, has been done with the declaration of Depok Trash Care towards Trash Clean 2020 in March 2014.
\end{abstract}

Keywords: community, environment, waste management

\section{INTRODUCTION}

Waste is one of those words that are so widely used we often forget to question what it really means (Urbanbandit, 2012). Wastes are materials that are not prime products (that is products produced for the market) for which the initial user has no further use in terms of his/her own purposes of production, transformation or consumption, and of which he/she wants to dispose (United Nations Environment Program (UNEP), 2005). According to (Williams, 2005), waste(s) (also known as rubbish, trash, refuse, garbage, junk and litter), is very subjective; one person may deem an item to be waste whilst another might see it as a resource.

Waste products arise from our ways of life and it is generated at every stage of production and development. It spans all stages of human activities, from manufacturing to consumption (Oyelola, et.al, 2011). It is especially a serious problem in developing countries where generation of waste per unit of output is much higher than that in the developed countries because of inefficiency in manufacturing processes (CointreauLevin, 2006).

Depok city is a city with a relatively high population growth with more than 2 million people which occupy 11 districts and 63 villages. The growth itself brings problems of waste that increase linearly. Although the Government has issued the Law (UU) No. 18 of 2008 on Waste Management and Government Regulation of the Republic of Indonesia No. 81 Year 2012 on Management of household waste and householdlike waste, but people of Depok was not considering the environmental conditions yet, even Depok ever received the predicate of dirtiest city across Indonesia in 2010. Depok City local Government along with the communities were very anxious and concerned over the predicate. Following up on the Indonesian Government Regulation No. 81 of 2012, particularly Chapter II regarding the waste management strategy, and Article 4 (3) which states that district / city government formulate and establish policies and strategies for district / city waste management. Depok City Government has issued a decree for Depok area No. 5 Year 2014 on Waste Management in an effort to overcome the problems of waste, mainly reduces the capacity of waste dumped in Final Disposal (TPA) which increase significantly. A number of policies have launched a movement of Clean Depok with priorities in some sectors and locations, such as the opening of the waste bank program in every neighborhood community which trigger residents to sort inorganic waste and then deposit it in the waste bank.

Another one is construction program of Waste Processing Unit, which processes organic waste into compost. In addition, cooperation with the institutions or technical ministries such as the Ministry of Public Works and the Ministry of Environment, as well as cooperation with Cell in order to achieve community empowerment, is starting to intensify information delivery. It is not merely managing physical trash only, but also involves the community through effective campaigns. Since 2012, Depok has launched Depok Waste Concern. In March 2014, Depok has also been declared a Depok Waste Concern towards Clean Waste at 2020.

The purpose of this study was to analyze the effectiveness of local government policies, community empowerment, environmental management and waste management technologies in Depok. The scope of this study includes the effectiveness of local government policies, community empowerment, environmental management and waste management technologies aspects. 


\section{LITERATURE REVIEW}

In every aspect of human life, several unwanted materials (newspapers, broken bottles, aluminum cans, flower trimmings, etc) are generated. These materials are discarded simply because they are considered waste to that effect (Abagale, et.al, 2012). (CTMA, 2004) stated that the total stream of waste generated within a community is often categorized into municipal waste, industrial waste, constructional and demolition waste. While (Alexander, 2015) cited that household waste streams in the county identified nine main types of materials: paper/card, plastic film, dense plastic, textiles, miscellaneous combustibles, glass, ferrous metal, garden waste and food waste.

Solid wastes are all the wastes arising from human and animal activities that are normally solid and are discarded or intend to discard as useless or unwanted. The term solid waste is all inclusive, encompassing the heterogeneous mass of throwaways from the urban community as well as the more homogeneous accumulation of agricultural, industrial, and mineral wastes (Tadesse, 2004; Agwu, 2012).

Solid waste management is the process of collecting, storing, treatment and disposal of solid wastes in such a way that they are harmless to humans, plants, animals, the ecology and the environment generally. The unhealthy disposal of solid waste is one of the greatest challenges facing developing countries (Kofoworola, 2007). While Magutu and Onsongo (2011) have said that Waste management practices differ for developed and developing nations, for urban and rural areas, and for residential and industrial producers.

Hasan (2004) reported that public awareness, community participation, appropriate legislation, and strong technical support are key components to successful municipal solid waste management. Subramanian (2005) argued environmentally sound management of MSW has received a prime focus by both the international community and most national governments. This is evidenced by previous papers about municipal solid waste in some less-developed Countries on various continents or island nations (Goorah, Esmyot, \& Boojhawon, 2009; Nasrabadi, Hoveidi, Bidhendi, Yavari, \& Mohammadnejad, 2008). Thus, a comprehensive MSW management regime should include administrative, financial, legal, planning, and engineering functions (Ramachandra \& Varghese, 2003).

\section{METHODOLOGY}

The method used in this research is descriptive method. The method is used for trying to find the fact about the effectiveness of Government Policies and local Government Policies of Depok West Java related with waste based environmental management, with the proper interpretation and accurately describe the nature and actions of the phenomenon of groups and individuals at the empirical level. Research design used in this study is a qualitative approach, which observe and capture reality and examine the behavior of individuals and groups as well as the experience of informants.

The qualitative approach is to introspect, retrospect, describing as it is, to experience and discover verstehen, uniqueness deeply, research a phenomenon, observe empirical causality and form a theory of data
(Ndraha, 2003). The emphasis of the qualitative approach in this study is based on the consideration that the focus in this study is to reveal the process and find the meaning of the local Government policy of Depok, West Java related to sustainable development and environmental insight. Qualitative approach is more relevant for disclosure process and interpretation of the meaning in a study.

Thus, the qualitative approach here is to understand the process of investigating the social or human problem, based on the creation of a holistic picture formed by the words, and reporting detailed views of informants. Furthermore, through triangulation techniques, researchers conducted a crosscheck data obtained from one informant and comparing data from interviews with observations with regard to local Government policy of Depok, West Java related to sustainable development and environmental insight. Overall data are obtained in the form of primary and secondary data. The main data source research using qualitative approach are words and actions, the rest is additional data, documents and others.

\section{Data Requirements, Source Data and Data Types}

In this study, the data required is related to sustainable development policies and environmental insight in Depok, West Java. The main data source is a qualitative research design with words and actions, the rest is additional data. The type of data needed is primary data which obtained directly from the informant, while secondary data is obtained from documents, literature as well as various product regulations relevant to the focus of research.

\section{Informant}

Informant, is a source of primary data which very important in this study. Therefore, the manner and requirement to determine the informant is crucial in this research in order to address concerns and research purposes. Informant is a source of primary data and determined by purposive sampling with direct appointment by researchers based on consideration that the informant actually understand the substance of the research (Moleong, 2006).

In this study, the informants are: (1) The City Secretary of Depok (Informant I); (2) The Secretary of the Department of Cleansing and Plantation (Informant II); (3) The Secretary of the Environment Agency Depok (Informant III); (4) and (5) Waste Bank Field Coordinator and Waste Management Unit (Informant IV \& V).

Data Collection Techniques / Instruments of Research

a. Interviews. Interviews were conducted in order to obtain sufficient data about the object of research. In this context, the researchers used in-depth interviews, with specified outline.

b. Observation (participant observation). This study using participative observation, which puts researchers as an integral part of the research object. Phenomena associated with this research object are direct observation on the activities at the sites. Data obtained through subsequent observations are recorded systematically, photographed or recorded. 
c. Visual images. Researchers obtain information and informant's opinions including the state of the research location recorded in the form of visual images, namely tape cassette and camcorder.

d. Primary and secondary data as well as examine various documents and regulation product relevant to the object of research.

\section{Validity Assessment and Data Processing Techniques}

Assessment of the validity of data in this study used triangulation techniques. This technique is achieved by checking and cross-checking comparison of data from observation and interview, as well as comparing the results of interviews with the contents of the document. It also compared the interview results of one informant with another (Cresswell, 2002).

Based on this technique, data processing procedure is accomplished as follows.

a. Collecting data by determining the data source and differentiates it in the category of primary and secondary data. Sorting or classifying the data and then performed in a structured and systematic recording of relevant data.

b. Criticizing the available data. Critics of the data are prepared to control and conduct recheck on the data whether relevant or not to be presented and interpreted. Furthermore, through triangulation techniques, researchers conducted a crosscheck data obtained from one informant with another and comparing data from interviews with observations and the existing formal data.

\section{RESULTS AND DISCUSSIONS \\ Government Policies Effectiveness}

According to Indonesia's National Encyclopedia; effectiveness is something that shows the level of achievement of a goal. An attempt could be said effective if it ideally achieves the goal of business.

Effectiveness of Government Policies concerning waste management refers to the (Act) No. 18 Year 2008 on the Waste Management, the Indonesian Government Regulation Number 81 Year 2012 as well as the latest Regulation No. 5 of 2014 on Waste Management. Regulation No. 5 of 2014, which in Chapter IV focuses on the planning, waste reduction and handling. Part one is "Planning and Master Plan" shows: 1) the City Government arrange reduction and waste management plan as outline in the strategic plan and annual work plans.

Next 2) Plan for waste reduction and handling as number 1) shall at least contain: a) waste reduction target b) providing waste reduction and handling facilities through landfill. c) The pattern of regional cooperation, partnership and community participation, d) financing requirements which provided by the local government and the community, and e) Plan for the development and utilization of environmentally friendly technology in meeting the needs of reuse, recycle and waste handlers.

Furthermore, in the Master Plan includes: 1) The local government prepared a master plan of waste management for a period of 10 (ten) years as outlined in the annual work plan. Master Plan as mentioned at 1) shall contain at least: a) restrictions on landfill waste (reduce); b) recycling bins (recycle); c) the reuse of waste (reuse); d) waste segregation; e) waste collection; f) waste transporting; g) waste treatment; h) final waste processing; and i) funding.

The results of interviews with informants I, II, III and the results of direct observation on the effectiveness of the implementation of government policies adopted by the central government and the local government as set out in Regulation Depok No. 5 of 2014 resulted that basically the local Government through the relevant Department, namely the Department of Cleansing and Plantation, has been implement to develop "Waste Bank" contained almost all neighborhood communities with the amount of approximately 500 waste banks, as well as the construction of Waste Treatment Unit located in districts, in order to overcome the accumulation of waste and reduce the capacity of the waste which brought to the final disposal of waste. The Waste Management Units which have been built and spread across districts up to present are stated in Table-1.

Referring to Waste Processing Unit, which spreads about 30 units across 11 districts and 63 villages, it means that Waste Processing Units are available almost every two villages. The construction of Waste Composting Unit was initially started with many protests from the communities which refuse its existence. With persuasive approach and the use of environmentally friendly technologies, until now the local government of Depok superbly managed to build Waste Processing Unit and planned to build it in every area of the village.

Table-1. Construction of Waste Processing Unit (UPS) up to 2014

\begin{tabular}{|c|c|c|c|}
\hline No & Location & $\begin{array}{l}\text { Land } \\
\text { Status }\end{array}$ & $\begin{array}{c}\text { Surface } \\
\text { Area }\end{array}$ \\
\hline 1 & TPA Cipayung (Hanggar 1) & $\mathrm{L}$ & $\pm 540 \mathrm{~m}^{2}$ \\
\hline 2 & TPA Cipayung (Hanggar 2) & $\mathrm{L}$ & $\pm 540 \mathrm{~m}^{2}$ \\
\hline 3 & TPA Cipayung (Hanggar 3) & $\mathrm{L}$ & $\pm 540 \mathrm{~m}^{2}$ \\
\hline 4 & TPA Cipayung (Hanggar 4) & $\mathrm{L}$ & $\pm 540 \mathrm{~m}^{2}$ \\
\hline 5 & $\begin{array}{l}\text { Jl. Merdeka (Hanggar 1), } \\
\text { Abadijaya, Sukmajaya }\end{array}$ & $\begin{array}{l}\mathrm{SP} / \\
\mathrm{PF}\end{array}$ & $\pm 466.24 \mathrm{~m}^{2}$ \\
\hline 6 & $\begin{array}{l}\text { Jl. Merdeka (Hanggar 2), } \\
\text { Abadijaya, Sukmajaya }\end{array}$ & $\begin{array}{l}\mathrm{SP} / \\
\mathrm{PF}\end{array}$ & $\pm 430 \mathrm{~m}^{2}$ \\
\hline 7 & Jl. Jawa, Beji, Depok Utara & $\begin{array}{l}\mathrm{SP} / \\
\mathrm{PF}\end{array}$ & $\pm 540 \mathrm{~m}^{2}$ \\
\hline 8 & $\begin{array}{l}\text { Jl. Sadewa Raya Depok } \\
\text { Tengah }\end{array}$ & $\begin{array}{l}\mathrm{SP} / \\
\mathrm{PF}\end{array}$ & $\pm 316.9 \mathrm{~m}^{2}$ \\
\hline 9 & $\begin{array}{l}\text { Kampung Lio, RT 03/07, } \\
\text { Bojong, Pondok Terong }\end{array}$ & $\mathrm{O}$ & $\pm 700 \mathrm{~m}^{2}$ \\
\hline 10 & $\begin{array}{l}\text { Jl. Pulo Mangga RT 02/05, } \\
\text { Grogol, Limo }\end{array}$ & $\mathrm{O}$ & $\pm 568 \mathrm{~m}^{2}$ \\
\hline 11 & $\begin{array}{l}\text { Bukut Rivaria, RW 014, } \\
\text { Bedahan, Sawangan }\end{array}$ & $\begin{array}{l}\mathrm{SP} / \\
\mathrm{PF}\end{array}$ & $\pm 1000 \mathrm{~m}^{2}$ \\
\hline 12 & $\begin{array}{l}\text { Cimpaeun RT 03/16, } \\
\text { Cimanggis }\end{array}$ & $\begin{array}{l}\mathrm{SP} / \\
\mathrm{PF}\end{array}$ & $\pm 500 \mathrm{~m}^{2}$ \\
\hline 13 & $\begin{array}{l}\text { Cilangkap RT 01/011, } \\
\text { Cimanggis }\end{array}$ & $\begin{array}{l}\mathrm{SP} / \\
\mathrm{PF}\end{array}$ & $\pm 400 \mathrm{~m}^{2}$ \\
\hline 14 & $\begin{array}{l}\text { Kampung Sasak, RT 03/06, } \\
\text { Limo }\end{array}$ & $\mathrm{O}$ & $\pm 700 \mathrm{~m}^{2}$ \\
\hline 15 & $\begin{array}{l}\text { Jl. Mesjid Nurul Huda, } \\
\text { RT01/06, Bojongsari } \\
\text { Sawangan }\end{array}$ & $\mathrm{O}$ & $\pm 1000 \mathrm{~m}^{2}$ \\
\hline 16 & $\begin{array}{l}\text { Jl. Cilobak Raya V, RT } 02 \\
\text { /01, Pangkalan, Jati, Limo }\end{array}$ & $\mathrm{O}$ & $\pm 500 \mathrm{~m}^{2}$ \\
\hline
\end{tabular}




\begin{tabular}{|c|c|c|c|}
\hline No & Location & $\begin{array}{l}\text { Land } \\
\text { Status }\end{array}$ & $\begin{array}{l}\text { Surface } \\
\text { Area }\end{array}$ \\
\hline 17 & $\begin{array}{l}\text { Jl. Bulak Timur RT 01/06, } \\
\text { Cipayung, Pancoran Mas }\end{array}$ & $\mathrm{O}$ & $\pm 600 \mathrm{~m}^{2}$ \\
\hline 18 & $\begin{array}{l}\text { Komplek Wika Realty Unit } \\
\text { II, Tamansari Puri Bali, } \\
\text { Curug, Sawangan }\end{array}$ & $\begin{array}{l}\mathrm{SP} / \\
\mathrm{PF}\end{array}$ & $\pm 500 \mathrm{~m}^{2}$ \\
\hline 19 & $\begin{array}{l}\text { Permata Regency, Jl. Raya } \\
\text { Citayam, Pondok Jaya, } \\
\text { Pancoran Mas }\end{array}$ & $\begin{array}{l}\mathrm{SP} / \\
\mathrm{PF}\end{array}$ & $\pm 500 \mathrm{~m}^{2}$ \\
\hline 20 & $\begin{array}{l}\text { Jl. Al-Hidayah, Pangkalan } \\
\text { Jati Baru, Limo }\end{array}$ & $\begin{array}{l}\mathrm{SP} / \\
\mathrm{PF}\end{array}$ & $\pm 500 \mathrm{~m}^{2}$ \\
\hline \multicolumn{4}{|c|}{ 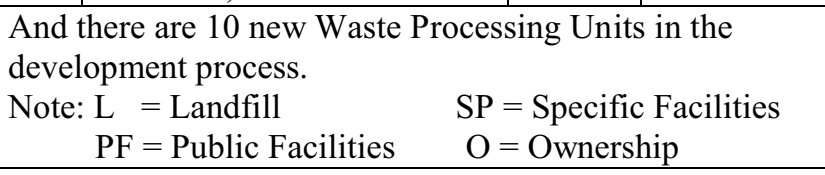 } \\
\hline
\end{tabular}

Source: DKP Administrative Information System, Depok 2014

\section{Aspects of Community Empowerment \\ Household Scale Community approach}

The very effective program in waste management is community empowerment which involving the community, especially at the level of home neighbors for sorting waste. Directing public awareness is not an easy effort. It is associated with culture changes and perspective. By involving all potential group that exists in society such as Cadre, Dasawisma, Youth, Prayer Groups, Religious and Community Leaders, as well as the universities that work in a coordinated, well-planned and sustainable, through continuous socialization, is expected to managed the culture changes and perspective. According to (Abduli, 1997), the development of permanent education and training programs for personnel involved in medical, hazardous, and municipal solid waste management is highly recommended. Hence, another program which also important related to public awareness is the socialization of materials about waste management in Depok. Through education in elementary and junior high school, children are also expected to be able to have perspective and culture that is more environmentally friendly.

The Government's main program for addressing the problem of waste is the $3 \mathrm{R}$ (reduce, recycle and reuse), by establishing Waste Bank and the construction of Waste Processing Unit (UPS). The program has been promoted since 2014 along with the publication of Regulation No. 5 Year 2014 concerning waste management. Through the Waste sorting socialization movement, continuously in every neighborhood, the waste banks are expected to be available in every neighborhood, while the residents should active and focus on waste management independently. Waste Bank is a concept to sort waste collection and has a management similar with banks, with waste saved instead of money. Residents who save also called customers and owned saving book.

The savings could be used for payment of electricity and water. Even residents might also borrow money that could be paid by dry waste that collected every week. Waste is saved in the form of dry waste or inorganic waste such as cardboard, glass, plastic bottle, can, iron, glass bottle, aluminum and mixed. The price of each kilogram varies according to its kind, as shown in Table2 below.
Table-2. Dry Waste Prices in Waste Bank Depok

\begin{tabular}{|l|c|}
\hline \multicolumn{1}{|c|}{ Dry Waste types } & Price per kg (Rp) \\
\hline Cardboard & 1.100 \\
\hline Plastic cup (clean) & 5.500 \\
\hline Plastic bottle & 3.000 \\
\hline Glass bottle & 300 \\
\hline Can & 1.800 \\
\hline Iron & 2.300 \\
\hline Aluminium & 9000 \\
\hline Mix & 1.400 \\
\hline
\end{tabular}

Source: DKP Administrative Information System, Depok 2014

Observations and interviews result with informants with the present of waste bank in each community neighborhood, citizens are very enthusiastic, participation of them to save in waste banks is quite high, which means that there is an increasing awareness of the public to take care of the environment. Almost in every community neighborhood in the area of Depok has opened waste bank they open every week in average. Citizens carrying dry waste that has been collected and sorted then brought it to the bank, weighed and write it in the saving book. Dry waste from the waste banks are collected and sent to the waste bank owned by Department of Cleansing and Plantation which also distributed in the districts. From the district waste banks, the dry waste then brought to industrial waste collector. The average dry waste collected in every district at waste collector is about $600 \mathrm{~kg}$ to $1000 \mathrm{~kg}$ per week; with funds returned to the communities are about 6 million to 10 million every week. With total of 11 districts, means that collected dry waste as much as $6,600 \mathrm{~kg}$ to $11,000 \mathrm{~kg}$. This is greatly helps the government of Depok, particularly in reducing the volume of the final disposal bins located in Cipayung, which lately has been full.

Waste Processing Unit Development that has been opened in several districts, that currently has reached 30 units; also expect the participation of the community in sorting organic or wet waste start from home. Through continuous socialization, residents in home neighborhood expected to sort organic / wet waste and place it in a small bucket, then by community officers is taken and collected in collecting point, then officers from the Department of Cleansing and Plantation subsequently collect it every 2 days and processed into compost at the Waste Treatment Unit of each district. The program is supposed to be effective in dealing with the waste problem if all residents are able to cooperate.

The results of direct observation and interviews with the informant, during the two years program of Depok Waste Care, until now the community has been implementing the program Depok Waste Care and environmental awareness towards Depok Waste Free, particularly the sorting of organic waste, recently reached $15 \%$ but from time to time through continuous socialization, started moving towards improvement, public awareness is also moving to increase. Some residents have also applied sorting starting from community neighborhood.

\section{Regional Scale Approach}

Program conducted by regional-scale approach is an effort to change the paradigm of waste management, 
namely collect-transport-dispose become collect-processbenefits. The programs are to build the Waste Processing Unit in the lower region scale (sub-district). Land required for 1 Waste Processing Unit is approximately $500 \mathrm{~m}^{2}$. In a four-year period, it is expected that waste processing units will dominate waste treatment in the city of Depok which took over the role of waste landfill.

With the achievement of performance indicators, integrated waste management is waste management at Waste Management Unit before being transported to the Final Waste Disposal. One (1) waste processing unit can handle as many as $30 \mathrm{~m}^{3} /$ day that will produce $2.4 \mathrm{~m}^{3}$ of recycled materials such as metal, paper and plastic that still have economic value, compost that equivalent with 1 ton of compost per day and absorb as much as 14 workers. The compost produced is marketed and used by farmers in the region of Depok, particularly on agriculture carambola, guava, vegetables and ornamental plants which estimated to use compost as much as 15,200 tons per year.

Depok Waste Concern Program is quite helpful in reducing the waste problem in local government of Depok. The capacity of waste dumped into the final disposal, is now decrease to $20 \%$. Household waste has been divided into inorganic waste and be brought to the Waste Bank, while organic waste processed in Waste Processing Unit, and the rest of residual waste dumped into the final disposal site (TPA). In accordance with Law No. 18 of 2008 on waste management stated that waste should not be disposed in the landfill, unless already be sorted out from the house and handled through UPS, while TPA can only hold the residual, dangerous and toxic wastes.

\section{Aspects of Environmental Management}

Clean environment is the desire of everyone. It is not easy to create such a clean and tidy environment that looks great on view. Along with the advanced level of education, people's minds and technologies, environmental awareness to have clean conditions must be improved. Clean and healthy environment conditions will make occupants feel comfort while healthy body is also maintained. Many benefits would be obtained by people when their environment is clean and tidy. Clean environment will diminish certain source of disease. This is certainly related to health matter. Moreover, with a clean environment, we will feel comfortable being at home.

Therefore, it is each individual responsibility to maintain cleanliness and healthiness of our environment. Although other external factors have influences to the health and clean conditions, but a clean home environment is the most important thing and should be prioritized in maintaining. Clean environments, which are free from waste, can prevent from disasters such as floods during monsoon. One of the causes of flooding in various regions is due to the large trash scattered thereby inhibiting the flow of water. This is one of the very bad behaviors that seemed to have become habit of most Indonesian society, especially in urban areas.

Observing and interviewing the respondents, it is then concluded that the habit of clean living in Depok still low yet has improved. Especially as the Depok City Government has built several waste treatment units, which is capable of reducing the waste problem about only $20 \%$.

The habitude of disposing waste to rivers and ditches means it is difficult to generate cleaner environment, however, to change the habit was not a simple thing to do. Limited land to be used as waste treatment site is one of the reasons of why people in Depok choose to dispose waste carelessly.

To generate a clean environment is the responsibility of every single human being, not only the government though its regulations. There are several steps to create a clean environment such as:

1. Provide awareness about the importance of a clean environment to public, especially to children so that this awareness will continue to grow by age. Familiarize clean life at early age is proven to be more effective than at mature.

2. Apply the habit of disposing waste to its place as early as possible. Introducing the habit to children will be more beneficial to create the pattern of good behavior in the subconscious. Waste is always a classic matter yet can be solved with simple things. Disposing waste into the trash bin for example, is the simple beginning to address the problem.

\section{Aspects of Technology}

Waste is often seen as a phenomenon that cannot be solved effectively. Various strategies have been carried out both by the Government of Depok and environment community. Public awareness is still low which roles only $15 \%$ but the gradually increased through continuous information and dissemination by Depok City Government through the Department of Sanitation, which is optimistic to process waste, organic communities increasingly Waste Processing Unit.

Likewise, the manufacture of "Waste Bank" is run by people in their environment. Public awareness to separate inorganic waste in the form of plastic, tin, rubber, tin, metal, iron and other materials has been noble, as it can be exchanged into savings. Inorganic waste can be recycled to reproduce recycle stuffs. Moreover, some areas even produce a good quality handicraft from inorganic materials.

As for organic waste such as leaves fall, trash from agricultural residue, waste from the kitchen vegetables, and other types of organic waste, they can processed to make compost that can be used by the community itself as fertilizers. Compost also has economic value and business opportunities that can be further developed. An added value can be obtained from the processing of organic waste into compost. Compost made from organic waste material can also be used for the treatment of plants in organic farming systems.

\section{Manufacturing process of compost from organic waste}

Producing compost from organic waste is quite simple and using simple tools such as buckets, chopping machines, sieving machines, spades, forks, levers, scales, and thermometer.

The compost material is organic waste such as leaves, vegetable scraps, grass, or even trash from agricultural residues and household waste. Depok has its own method for composting process which is not 
involving active materials such as sugar, EM4. However, the bacteria obtained from the leaf litter leaves were allowed to stand for 3 days. From its process, the leaves' decomposition will grow bacteria, which is the active ingredient of fermentation process.

\section{How to make}

1. Organic waste collected from households, leftover vegetables from the market divided and separated from the rest of the inorganic such as plastic, etc., while the leaves of leaf litter from the felling of trees chopped and allowed to stand for 3 days until the bacteria generates. The leaves must have sufficient moisture content by giving splashes of water to grow the bacteria.

2. Combine ingredients strips of household waste and leaf litter in the ratio 1: 1 . Then pile them for 3 months. Each pile is then weighed, coded, and marked the start date. Observe the temperature during the process every two weeks, as the temperature will continue to rise to approximately $80^{\circ} \mathrm{C}$ due to the fermentation process. After reaching the maximum temperature, typically the pile will have reduced in temperature. As the temperature drops, the pile is being conversed, to give the opportunity to the fermentation process by keeping the humidity. The processes are applied several times until a stable temperature reaches room temperature.

3. Next, the piles are sieved to obtain compost and allowed to stand for 1 month.

4. Fertilizer compost is ready to be harvested, put in pouch bags and weighed with a capacity of $10 \mathrm{~kg}$ per bag.

For the record, if the water in the trash is excessive, it will cause a foul odor causing maggots grow, conversely, if the temperature is hot, then cooled or inverted, then the degrading microorganism will die causing poor quality organic compost.

Waste processing technology in Depok is quite inefficient. It is necessary to add the cost of EM4 and other supporting chemicals. Improvement need to be conducted as there are many visits by the governments and various other areas for a comparative study on waste management in Depok.

\section{CONCLUSIONS}

In the realization of the policy and regulation of Government of Depok in environmental management based on effective waste, it can be concluded that:

1. Institutional Regulations for Waste Management in Depok has been effective. This was evidenced by the good cooperation between the government and the public of Depok especially in socializing the regulation. It has been proven that the society is enthusiastically joining the socialization event in many areas in Depok.

2. Public awareness to create a clean environment of Depok has been growing rapidly. This is evidenced by the presence of active Waste Bank in many areas in Depok. However, in creating public awareness of clean living from organic waste is only about $15 \%$, but it is continued to rise in line with the amount of construction waste Processing Unit growing and declining capacity of waste in landfill.
3. Waste treatment technologies in Depok Waste Processing Unit, is simple in technology yet efficient and effective, as it need no chemicals such as EM4 and sugar solution, but only bacteria as the result of decomposition. The resulting compost is a standardized compost.

\section{REFERENCES}

Abagale, K. F., Mensah, A., and Osei, A. R. 2012. Urban Solid Waste Sorting in A Growing City of Ghana. International Journal of Environment and Sustainability, Vol.1, No. 4, Pp 18-25, available online at www.sciencetarget.com, accessed on November $20^{\text {th }}$, 2015

Abduli, M.A. 1997. Solid Waste Management in Guilan Province, Iran. Journal of environmental health, vol. 59, no. 10 , pp. 19-24.

Agwu, M. O. 2012. Issues and Challenges of Solid Waste Management Practices in Port-Harcourt, Nigeria - a Behavioral Perspective. American Journal of social and management of sciences, available online at http://www.scihub.org/AJSMS/PDF/2012/2/AJSMS-3-283-92.pdf, accessed on November $19^{\text {th }}, 2015$.

Alexander, F.O., Anan, J. \& Matilda, O.B. 2015. An Assessment of Solid Waste Management System in the Kumasi Metropolis. Journal of Arts and Humanities, vol. 4, no. 3, pp. 27-39, available online at http://www.theartsjournal.org/index.php/site/article/view File/663/354, accessed on November $19^{\text {th }}, 2015$.

Cape Town Metropolitan Assembly (CTMA). 2004. Integrated waste management. Republic of South Africa

City Regulation of Depok Number 5 Year 2014 about Waste Management

Cointreau-Levin, S. 2006. Occupational and Environmental Health Issues of Solid Waste Management: Special Emphasis on Middle- and Lower-income Countries. World Bank Report, and Pp 1-41, available online at http://siteresources.worldbank.org/INTUSWM/ Resources/up-2.pdf, accessed on November 20th, 2015

Cresswell, John W. 2002. Research Design. Quantitative \& Qualitative Approaches, New York: Sage Publication, Inc.

Goorah, S.S.D., Esmyot, M.L.I., \& Boojhawon, R. 2009. The Health Impact of Nonhazardous Solid Waste Disposal in a Community: The Case of the Mare Chicose Landfill in Mauritius. Journal of Environmental Health, 72(1), 48-54.

Government Regulation of the Republic of Indonesia Number 81 Year 2012 about Management of household waste and household-like waste

Hasan, S.E. 2004. Public Awareness is Key to Successful Waste Management. Journal of Environmental Science and Health, A39(2), 483-492. 
Kofoworola, O. F. 2007. Recovery and Recycling Practices in Municipal Solid Waste Management in Lagos, Nigeria. Waste Management Journal, Vol. 27, No. 9, Pp 1139-1143.

Law (UU) Number 18 Year 2008 about Waste Management.

Maguto, P.O., and Onsongo, C.O. 2011. Operationalizing Municipal Solid Waste Management. Integrated Waste Management Journal, Vol. II, Pp 1-9, available online at http://www.intechopen.com/books/ integrated-wastemanagement-volume-ii/operationalizing -municipalsolid-waste-management, accessed on November $19^{\text {th }}$, 2015

Moleong, Lexy J. 2006. Qualitative Research Methodology, 22 ${ }^{\text {nd }}$ edition, Bandung: PT Remaja Rosdakarya

Nasrabadi, T., Hoveidi, H., Bidhendi, G.N., Yavari, A.R., \& Mohammadnejad, S. 2008. Evaluating Citizen Attitudes and Participation in Solid Waste Management in Tehran, Iran. Journal of Environmental Health, 71(5), 30-33.

Ndraha, Taliziduhu. 2003. Methodology of Indonesian Government, $3^{\text {rd }}$ edition. Jakarta: Bina Aksara, p. 57.

Oyelola, O. T., Babatunde, A. I., and Abiodun, A. A. 2011. Appraisal of Municipal Solid Waste Management in Lagos Metropolis. Wilolud Journals, Vol. 2, No. 2, Pp 1-7, (available online at https://www.researchgate.net/ publication/265349558_APPRAISAL_OF_MUNICIPAL SOLID_WASTE_MANAGEMENT_IN_LAGOS_MET $\overline{\mathrm{R} O P O L I S})$, accessed on November $2 \overline{0}^{\mathrm{t}}, \overline{2015 .}$

Ramachandra, T.V., \& Varghese, S.K. 2003. Exploring Possibilities of Achieving Sustainability in Solid Waste Management. Indian Journal of Environmental Health, 45(4), 255-264

Subramanian, K. 2005. Solid Waste Management Issues in Indian Cities. Chennai, India: The Hindu, available online at http://www.hindu.com/ accessed on November $21^{\text {st }}, 2015$.

Tadesse, T. 2004. Solid Waste Management. Lecture Notes for Environmental and Occupational Health Students, Ethiopia Public Health Initiative, Pp 1-199.

United Nations Environment Programme. 2005. Solid Waste Management, Chapter III: Waste Quantities and Characteristics, Pp 31-38, available online at hhtp://unep.or.jp, accessed on November $21^{\text {st }}, 2015$.

Urbanbandit Website. 2012. What is waste? Zero Waste Advocate and Urban Environmentalist", available online on http://urbanbandit.ca/2012/11/05/what-is-waste/, accessed on November 19th, 2015.

Williams, P. 2005. Waste Treatment and Disposal, Second edition, John Wiley and Sons Ltd, Chichester, Pp 380 . 